KA N D A I

\begin{tabular}{|l|l|l|}
\hline Volume 15 & No. 1, Mei 2019 & Halaman 47-60 \\
\hline
\end{tabular}

\title{
REALISASI TINDAK KESANTUNAN BERBAHASA PADA KOMENTAR AKUN INSTAGRAM JOKOWI: STUDI POLITIKOPRAGMATIK \\ (Realization of Language Courtesy on Jokowi's Instagram Account Comments: Politicopragmatic Study)
}

\author{
Hari Kusmanto, Harun Joko Prayitno \& Abdul Ngalim \\ Universitas Muhammadiyah Surakarta \\ Jalan A. Yani Tromol Pos 1, Kartasura, Surakarta, Indonesia \\ Pos-el: harikusmanto.ums@gmail.com
}

(Diterima 29 Januari 2019; Direvisi 1 Mei 2019; Disetujui 6 Mei 2019)

\begin{abstract}
This study aims to describe the language politeness strategy used by netizens in commenting Jokowi's Instagram account. The data in this study are in the form of words, phrases, and sentences that have the value of positive politeness and negative comments on Jokowi's Instagram account. The data sources in this study are comments on Jokowi's Instagram account. Data collecting in this study using the documentation method, skillful involvement free technique (SBLC). The data analysis in this study uses an intralingual and pragmatic equivalent. The results of this study show that the strategy of politeness of netizens in commenting on the Jokowi's Instagram account is realized with two strategies, namely the strategy of positive and negative politeness. Positive politeness strategies are realized into nine forms which include giving attention, showing optimism, using identity markers, giving question, involving speakers in communication, intensifying the attention of speakers by dramatizing events and facts, paying attention to the wishes of the speech partner, giving promises, and using jokes. Negative politeness strategies are realized into three forms which include apologizing, showing pessimism, using impersonal forms. This shows that netizens of Jokowi's Instagram account have confidence in Jokowi's leadership.
\end{abstract}

Keywords: politeness of language, Instagram, Jokowi, politicopragmatic

Abstrak

Studi ini bertujuan mendeskripsikan strategi kesantunan berbahasa yang digunakan netizen dalam berkomentar pada akun Instagram Jokowi. Data dalam studi ini berupa kata, frasa, dan kalimat yang memiliki nilai kesantunan positif dan negatif komentar pada akun Instagram Jokowi. Sumber data dalam studi ini adalah komentar-komentar pada akun Instagram Jokowi. Pengumpulan data dalam studi ini menggunakan metode dokumentasi dan simak dilanjutkan teknik bebas libat cakap (SBLC). Analisis data dalam studi ini menggunakan padan intralingual dan padan pragmatis. Hasil studi ini menunjukkan bahwa strategi kesantunan netizen dalam berkomentar pada akun Instagram Jokowi direalisasikan dengan dua strategi yaitu strategi kesantunan positif dan negatif. Strategi kesantunan positif direalisasikan menjadi sembilan wujud, yaitu memberikan perhatian, menunjukkan sikap optimis, menggunakan penanda indentitas, memberikan pertanyaan, melibatkan penutur dalam komunikasi, mengintensifkan perhatian penutur dengan cara mendramatisasi peristiwa dan fakta, memperhatikan keinginan mitra tutur, memberikan janji, dan menggunakan lelucon. Strategi kesantunan negatif direalisasikan menjadi tiga bentuk, yaitu meminta maaf, menunjukkan sikap pesimis; dan menggunakan bentuk impersonal. Hal ini menunjukkan bahwa netizen pada akun Instagram Jokowi memiliki kepercayaam terhadap kepemimpinan Jokowi.

Kata-kata kunci: kesantunan berbahasa, Instagram, Jokowi, politikopragmatik 
DOI: 10.26499/jk.v15i1.1269

How to cite: Kusmanto, H., Prayitno, H. J., \& Ngalim, A. (2019). Realitas tindak kesantunan berbahasa pada komentar akun Instagram Jokowi: Studi politikopragmatik. Kandai, 15(1), 47-60 (DOI:10.26499/jk.v15i1.1269)

\section{PENDAHULUAN}

Ihwal tindak kesantunan berbahasa perlu mendapat perhatian dan teladan. Praktik-praktik kesantunan dalam berbahasa saat ini mengalami degradasi. Cukup banyak praktik ketidaksantunan berbahasa yang terjadi. Beberapa publikasi mengenai praktik penggunaan bahasa yang tidak santun, di antaranya Hamzah dan Hassan (2012) membahas tentang mencaci, menghina, dan mengusir remaja lain. Mansor, et al (2014) berfokus pada pembahasan bahasa mengejek dan menggunakan kata kasar seperti bodoh. Penggunaan kritik secara langsung, penggunaan kata kasar, menyerang aspek pribadi orang lain, dan menebarkan kebencian ditulis oleh Kusno dan Rahman (2016). Publikasi kajian mengenai pergeseran dan defisit kesantunan berbahasa (Noor \& Prayitno, 2016), serta penggunaan bahasa disfemia pada media sosial Instagram (Ulum \& Kusmanto, 2018).

Berdasarkan temuan penelitian terdahulu yang disebutkan di atas telah banyak ditemukan bentuk ketidaksantunan berbahasa baik di lingkungan pendidikan maupun media sosial seperti Instagram. Oleh karena itu, perlu adanya praktik baik dalam bersosial media atau santun bermedia, lebih khusus dalam studi ini adalah santun berkomentar dalam Instagram.

Salah satu praktik santun berinstagram dapat ditemukan pada komentar-komentar akun Instagram Jokowi. Instagram Jokowi merupakan salah satu akun Instagram pejabat negara dengan pengikut paling banyak. Pengikut akun Instagram Jokowi mencapai 16 juta. Berdasarkan hal tersebut dialektika kesantunan berkomentar pada akun Instagram
Jokowi menarik untuk diteliti dengan perspektif politikopragmatik.

Berikut ini disajikan dua contoh untuk menunjukkan strategi kesantunan berbahasa pada komentar akun Instagram Jokowi dengan konteks Jokowi mengunggah kegiatannya di Stadion Gelora Bung Karno, pada saat pembukaan Asian Para Games 2018.

"Sehat selalu pak Jokowi biar bisa memimpin Indonesia 5 tahun lagi... Indonesia sangat membutuhkan pemimpin seperti bapak" (nawaty0, 7-10-2018).

$\begin{array}{lcr}\text { Contoh } & \text { komentar di } & \text { atas } \\ \text { merupakan } & \text { wacana } & \text { politik } \\ \text { kepemimpinan. } & \text { Komentar } & \text { tersebut } \\ \text { disampaikan oleh pemilik } & \text { akun } \\ \text { Instagram nawaty0 dengan } & \text { tujuan }\end{array}$
Instagram nawaty0 dengan tujuan mengomentari unggahan Jokowi pada akun Instaramnya terkait acara pembukaan Asian Para Games 2018, di Stadion Gelora Bung Karno. Komentar Sehat selalu pak Jokowi biar bisa memimpin Indonesia 5 tahun lagi merupakan strategi tindak kesantunan positif dengan memperhatikan mitra tutur. Ada pula komentar yang menunjukkan komentar berstrategi kesantunan negatif dalam konteks Jokowi membuat unggahan mengenai ajakan untuk percaya diri terhadap bangsa Indonesia.

"Maaf pak Jokowi, saya mau
bertanya apakah
(rohmaddarmawan96,
2019).

Komentar di atas disampaikan oleh pemilik akun Instagram rohmaddarmawan96. Komentar tersebut merupakan respon terhadap unggahan 
Jokowi yang mengajak untuk optimis dalam membangun bangsa Indonesia. Komentar tersebut memiliki nilai kesantunan yang sangat baik, karena kata maaf sebagai wujud hormat dan memohon (Saputry, 2016).

Penelitian mengenai strategi kesantunan positif telah dilakukan Jauhari dan Sugiri (2012) dengan fokus bahasan kesantunan positif dalam masyarakat Tionghoa di Surakarta. Dalam penelitian Jauhari dan Sugiri ditemukan empat wujud kesantunan positif yang meliputi penggunaan istilah kekerabatan, penyebutan nama secara langsung, pemakaian bahasa Jawa jenis ngoko, dan penggunaan bahasa serta unsur bahasa Mandarin.

Penelitian mengenai strategi kesantunan selanjutnya dilakukan Gunawan (2014) yang mengangkat permasalahan representasi kesantunan Brown dan Levinson dalam wacana akademik. Gunawan mengungkapkan bahwa tindak komunikasi antara mahasiswa dan dosen menggunakan dua strategi yakni strategi kesantunan negatif dan positif.

Penelitian kesantunan positif selanjutnya dilakukan Rija (2016) yang meneliti strategi kesantunan positif pada novel The Client. Temuan Rija dalam penelitiannya adalah teridentifikasinya sebelas strategi kesantunan positif dalam novel The Client. Strategi kesantunan yang paling dominan adalah penggunaan penanda identitas, sedangkan makna komentar yang paling banyak adalah ajakan.

Penelitian kesantunan positif juga dilakukan oleh Syaifudin (2017) dan Kamlasi (2017). Syaifudin menemukan sebelas wujud kesantunan positif dan Kamlasi menemukan empat belas wujud kesantunan positif yang meliputi: (1) penggunaan ucapan salam, mengucapkan terima kasih, (3) memberi pujian, (4) meminta maaf, memberikan selamat, (6) keintiman, (7) mematuhi (8) memberikan pertanyaan, (10) permintaan, (11) memberikan saran,

(12) melakukan penolakan, memberikan hukuman, dan menunjukkan ketidaksepakatan.

Penelitian yang dilakukan oleh Prayitno, et al (2018) menemukan bahwa kesantunan guru dan siswa SD berlatar budaya Jawa ditunjukkan melalui empat hal, yaitu: (1) membangun sifat psikologis sebagai inti kesantunan positif dan karakter bangsa diwujudkan dengan meningkatkan rasa empati, mencari kesepakatan, memberi rasa hormat, menghargai pencapaian, dan memberikan keuntungan kepada orang lain; (2) memprioritaskan tugas bukan hak; (3) menciptakan strategi tindakan yang efektif dengan memosisikan pendengar; dan (4) menghormati orang lain untuk menunjukkan kesantunan.

Guna mengisi ruang yang belum banyak dibahas, berdasarkan uraian penelitian terdahulu di atas, masalah yang dikaji dalam studi ini difokuskan pasa kolom komentar media sosial, khususnya komentar pada akun Instagram Jokowi. Permasalahan yang diangkat adalah bagaimanakah strategi tindak kesantunan berbahasa yang digunakan netizen dalam berkomentar pada akun Instagram Jokowi? Sejalan dengan masalah tersebut, tujuan penelitian ini adalah mendeskripsikan strategi tindak kesantunan netizen dalam berkomentar pada akun Instagram Jokowi.

\section{LANDASAN TEORI}

Tindak kesantunan berbahasa sebagai salah satu perilaku berbahasa harus memperhatikan etika. Hal ini juga dinyatakan Zamzani (2010) kesantunan berbahasa (politeness) diekspresikan dengan cara yang baik dan beretika 
dalam berkomunikasi (Kusno \& Rahman, 2016).

Kesantunan berbahasa merupakan tindak komunikasi yang mengikat antara penutur dan mitra tutur untuk berkomunikasi dengan bahasa yang baik. Kesantunan merupakan cara yang ditempuh penutur dalam komunikasi agar mitra tutur tidak merasa tertekan, tersudut, atau tersinggung (Markhamah \& Sabardila, 2009). Kesantunan adalah bentuk perilaku yang disepakati dalam hubungan antarpersonal yang memiliki kesesuaian dan memberikan makna yang saling menghargai (Ngalim, et.al, 2015).

Kesantunan berbahasa menurut Brown dan Levinson (dalam Fauziati, 2016, hlm. 145) adalah usaha penutur untuk menjaga harga diri atau wajah mitra tutur yang dapat diwujudkan melalui beberapa strategi. Ada lima strategi kesantunan yang dapat digunakan dalam tindak komuikasi, yakni melakukan tindak tutur secara langsung tanpa basa-basi, melakukan tindak tutur dengan menggunakan strategi kesantunan positif, menggunakan strategi kesantunan negatif, menggunakan tindak tutur secara tersamar atau tidak langsung, dan bertutur dalam hati atau tidak melakukan tindak tutur (Brown \& Lenvinson, dalam Leech, 2014) .

Kajian pragmatik dan wacana politik selama ini masih terpisah, sehingga perlu adanya integrasi yang disebut studi politikopragmatik. Studi politikopragmatik merupakan kajian kebahasaan pada wacana politik. Studi kebahasaan yang mendasarkan pada pesan-pesan politik untuk dapat dijadikan sebagai kajian politik melalui politikopragmatik. Kajian politikopragmatik dalam konteks penelitian ini adalah mengkaji strategi tindak kesantunan berbahasa pada komentar akun Instagram Jokowi (Prayitno, 2015).
Berdasarkan pendapat yang telah dikemukakan Prayitno, studi politikopragmatik merupakan subdisiplin antara bidang politik dengan pragmatik yang mengkaji masalah kesantunan berbahasa pada wacana politik. Wacana politik dalam studi ini meliputi politik kepemimpinan, politik pembangunan, politik kesehatan, politik keagamaan, dan politik olahraga.

Kesantunan positif merupakan strategi komunikasi yang menggunakan bahasa yang sopan, santun dan berbudaya. Pemilihan strategi kesantunan positif dalam tindak komunikasi bertujuan untuk meningkatkan kesopanan dalam berkomunikasi (Jabbarifar, 2016). Salah satu strategi yang dapat digunakan oleh pemimpin untuk menunjukkan citra yang baik kepada masyarakat adalah dengan melakukan komunikasi yang santun (Arumsari et.al, 2017). Terkait dengan mitra tutur, tindak tutur dengan melebihkan perhatian kepada mitra tutur merupakan bentuk penghormatan (Halid, 2017). Dalam konteks politik, fungsi komunikasi yang santun adalah salah satu faktor penting untuk perencanaan dan implementasi pembangunan (Akadun, 2011).

Kesantunan positif berfungsi sebagai ekspresi perhatian dan optimisme (Hendrastuti, 2017). Sementara itu, penggunaan penanda identitas dalam tindak komunikasi bertujuan untuk membangun solidaritas (H.K, et.al, 2014). Penggunaan penanda identitas merupakan strategi pengembangan komunikasi kepemimpinan yang berkualitas (Nickerson \& Goby, 2017). Penggunaan penanda identitas juga berfungsi mengekspresikan kesantunan positif (Jauhari \& Susanto, 2014). Sukarno (2018) lebih lanjut menyatakan bahwa tujuan berbahasa dengan santun untuk menyelamatkan dan melindungi wajah 
mitra tutur, dengan demikian akan tercipta komunikasi yang berkualitas. Strategi lainnya adalah dengan memberikan pertanyaan kepada mitra tutur untuk menghindari perselisihan dan menunjukkan keramahan kepada mitra tutur (Maros \& Rosli, 2017).

Arsith, et al (2017) menyatakan bahwa peranan komunikasi agama sangat penting untuk menjaga dan melestarikan tatanan sosial. Komunikasi politik dalam bidang kesehatan memiliki andil yang besar dalam mewujudkan keberhasilan program atau kebijkan pemerintah khususnya dalam bidang kesehatan (Muhawarman, et al, 2017). Pelibatan mitra tutur pada wacana politik kesehatan di atas terlihat dengan penggunaan kata kita. Penggunaan kata kita pada data di atas memberikan daya kesantunan positif (Jauhari, 2018).

Memperhatikan keinginan mitra tutur sebagai salah satu strategi komunikasi untuk memperlihatkan integritas dan solidaritas kepada mitra tutur (Kousar, 2015). Fungsi komunikasi kepemimpinan adalah membentuk persepsi bersama. menyatakan komunikasi kepemimpinan bertujuan untuk mencapai tujuan yang lebih tinggi, khususnya dalam kepemimpinan (Mayfield \& Mayfield, 2017).

Tindak kesantunan positif berjanji mengikat penutur untuk melakukan sesuatu di masa yang akan datang (Saleh \& Baharman, 2012). Memberikan janji kepada mitra tutur bertujuan menjaga harmoni dan meningkatkan solidaritas (Aziz, 2017), sedangkan fungsi humor dalam komunikasi menyelamatkan wajah positif (Dynel, 2016). Pramujiono (2008) menyatakan penggunaan humor dalam berkomunikasi bertujuan untuk menimbulkan keakraban. Strategi kesantunan juga dapat berupa kata maaf sebagai wujud hormat dan memohon kepada mitra tutur (Saputry, 2016). Penyampaian informasi terkait dengan kesadaran pembangunan sebagai upaya mendukung keberhasilan pembangunan Listyawati (2019). Tindak komunikasi kepemimpinan yang dibangun oleh pemimpin seharusnya komunikasi yang berdaya kharismatik (Jamal \& Bakar, 2017).

\section{METODE PENELITIAN}

Metode yang digunakan adalah deskriptif kualitatif yang digunakan untuk menghasilkan data tertulis, yakni deskripsi strategi kesantunan positif dan negatif komentar pada akun Instagram Jokowi. Sumber data penelitian adalah akun Instagram Jokowi dan data berupa komentar pada akun Instagram tersebut. Data dipilih dan dipilah berupa komentar netizen pada akun Instagram Jokowi yang memiliki nilai kesantunan berbahasa (kesantunan positif dan negatif).

Data dikumpulkan dengan menggunakan teknik dokumentasi dan simak dilanjutkan dengan teknik simak bebas libat cakap (SBLC). Dokumen yang dimaksud dalam studi ini berupa komentar netizen dalam akun Instagram Jokowi. Metode simak dalam studi ini dilakukan dengan melakukan penyimakan, yakni menyimak penggunaan bahasa netizen saat berkomentar pada akun Instagram Jokowi. Selanjutnya, setelah diperoleh data melalui penyimakan dilakukan pencatatan data pada kartu data sesuai dengan strategi kesantunan berbahasa.

Analisis data dalam studi ini menerapkan metode padan intralingual (Mahsun, 2014) dan padan pragmatis (Sudaryanto, 2015). Metode padan intralingual digunakan untuk mengidentifikasi strategi kesantunan berbahasa komentar netizen pada akun Instagram Jokowi. Langkah-langkah yang dilakukan adalah menganalisis komentar-komentar netizen akun 
instagram Jokowi berdasarkan wujud kesantunan positif. Selanjutnya peneliti menganalisis komentar akun Instagram Jokowi dan mengaitkan pada teori yang digunakan. Metode padan pragmatis digunakan untuk menentukan konteks komentar yang dapat ditelusuri pada akun Instagram Jokowi.

\section{PEMBAHASAN}

Berdasarkan analisis data yang telah dilakukan menunjukkan strategi berkomentar pada akun Instagram Jokowi diwujudkan melalui dua strategi kesantunan. Kedua strategi kesantunan tersebut adalah strategi kesantunan postif dan strategi kesantunan negatif. Berikut ini strategi kesantunan yang digunakan netizen dalam berkomentar pada akun Instagram Jokowi.

\section{Strategi Kesantunan Positif (KP)}

Kesantunan positif dalam komentar akun Instagram Jokowi direalisasikan menjadi beberapa wujud. Berikut ini perwujudan strategi kesantunan positif pada komentar akun Instagram Jokowi yang meliputi: (1) memberikan perhatian; (2) menunjukkan keoptimisan; (3) menggunakan penanda indentitas; (4) memberikan pertanyaan; (5) melibatkan penutur dalam komunikasi; (6) mengintensifkan perhatian penutur dengan cara mendramatisasi peristiwa dan fakta; (7) memperhatikan keinginan mitra tutur; (8) memberikan janji; dan menggunakan lelucon.

\section{KP-1: Memberikan Perhatian}

Memberikan perhatian kepada mitra tutur sebagai salah satu strategi kesantunan positif. Tindak komunikasi akan dapat mencapai tujuan komunikasi apabila antara penutur dan mitra tutur saling memberikan perhatian. Terdapat beberapa hal yang harus diperhatikan dalam merealisasikan tindak kesantunan berbahasa yang meliputi: memperhatikan topik, situasi, dan konteks pembicaraan (Saputry, 2016). Hal tersebut terlihat pada komentar komentar akun Instagram Jokowi dengan konteks Jokowi mengunggah postingan mengenai pertemuan IMF-Bank di Bali.

(1) "Semoga pak Jokowi sehat selalu dalam memimpin bangsa yang besar ini" (kadupe_laia, 19-10-2018)

Data (1) merupakan wacana politik kepemimpinan. Komentar pada data tersebut disampaikan oleh pemilik akun Instagram kadupe_laia sebagai respon unggahan Jokowi sebelumnya.

Salah satu strategi yang dapat digunakan oleh pemimpin untuk menunjukkan citra yang baik kepada masyarakat adalah dengan melakukan komunikasi yang santun. Komentar komentar di atas merupakan komentar yang mendayagunakan strategi kesantunan positif yang diwujudkan melalui memberikan perhatian kepada mitra tutur. Penutur dalam komentar tersebut memberikan perhatian yang lebih kepada Jokowi melalui komentarnya. Hal ini terlihat pada komentar Semoga pak Jokowi sehat selalu dalam memimpin bangsa yang besar ini.

Tindak tutur dengan melebihkan perhatian kepada mitra tutur merupakan bentuk penghormatan. Saling memberikan perhatian dalam tindak komunikasi antara pemimpin dan rakyat yang dipimpin menjadi penting suipaya tujuan komunikasi dapat tercapai. Wacana politik kepemimpinan pada data di atas relevan dengam pemilihan presiden dan wakil presiden 2019. Kontekstasi Pilpres sudah seharusnya 
direalisasikan dengan kesantunan berpolitik.

\section{KP-2: Menunjukkan Keoptimisan}

Strategi berkomunikasi dengan santun pada suatu komentar komunikasi dapat dilakukan dengan cara menunjukkan rasa peracaya diri kepada mitra tutur. Hal ini terlihat pada komentar dalam konteks Jokowi mengunggah suasana di jalur Trans Papua berikut.

(2) "Lanjut pakde teruskan pembangunan Papua sampai tersambung" (michaels4pi, 1611-2018).

Data (2) merupakan wacana politik pembangunan. Komentar tersebut disampaikan oleh pemilik akun Instagram michaels4pi dengan tujuan merespon unggahan Jokowi. Strategi kesantunan positif yang digunakan netizen dalam berkomentar pada data di atas diwujudkan melalui penggunaan kata yang berorientasi percaya diri.

Wacana politik pembangunan yang ditampilkan pada wacana tersebut relevan dengan program-program Jokowi. Fungsi komunikasi yang santun adalah sebagai salah satu faktor penting untuk perencanaan dan implementasi pembangunan. Program pembangunan yang dilakukan Jokowi berorientasi pada pembangunan fisik, seperti jalan tol, bendungan, dan sebagainya. Komentar tersebut sebagai strategi memberikan rasa percaya diri dengan program pembangunan. menyatakan sikap kesantunan positif berfungsi sebagai ekspresi perhatian dan optimisme.

\section{KP-3: Menggunakan Penanda Identitas}

Strategi kesantunan dalam berkomunikasi juga dapat direalisasikan dengan cara menggunakan penanda identitas yang dalam tindak komunikasi bertujuan untuk membangun solidaritas. Berikut komentar dengan konteks Jokowi bertemu Yusril Ihza Mahendra.
(3) "Pokok e pakde Jokowi 2 periode" (rasyd3942, 30-11- 2018).

Data (3) merupakan wacana politik kepemimpinan. Komentar tersebut disampaikan oleh pemilik akun Instagram rasyd3942 sebagai respon terhadap unggahan Jokowi. Komentar tersebut merupakan kesantunan berbahasa berstrategi positif dengan menggunakan penanda identitas sebagai strategi pengembangan komunikasi kepemimpinan yang berkualitas. Penggunaan penanda pakde pada wacana politik kepemimpinan bertujuan untuk menunbuhkan rasa kedekatan antara penutur dengan mitra tutur dan berfungsi mengekspresikan kesantunan positif. Tujuan berbahasa dengan santun untuk menyelamatkan dan melindungi wajah mitra tutur agar tercipta komunikasi yang berkualitas.

\section{KP-4: Memberikan Pertanyaan}

Strategi kesantunan dalam berkomunikasi yang selanjutnya dapat direalisasikan dengan cara memberikan pertanyaan mengenai apa yang telah disampaikan mitra tutur sebagai strategi untuk menghindari perselisihan dan menunjukkan keramahan kepada mitra tutur. Melalui pertanyaan yang diberikan oleh penutur menunjukkan bahwa penutur memberikan perhatian kepada mitra tutur. Berikut ini komentar yang memberikan pertanyaan kepada Jokowi dalam konteks hari santri.

(4) "Satu pertanyaan saya apa pendapat pak presiden yang saya hormati tentang pembakaran bendera kalimat tauhid, yang membuat hampir seluruh umat 
Islam di Indonesia turun ke jalan?" (egir432, 22-11-2018).

Data (4) merupakan wacana politik keagamaan. Komunikasi keagamaan sebagai salah satu strategi untuk menjaga kerukunan. Peranan komunikasi agama sangat penting untuk menjaga dan melestarikan tatanan sosial. Komentar dari akun Instagram egir432 ini sebagai respon memberikan pertanyaan kepada Jokowit sebagai salah satu bentuk perhatian terhadap mitra tutur.

\section{KP-5: Melibatkan Penutur dalam Komunikasi}

Tujuan tindak komunikasi akan dapat tercapai apabila penutur melibatkan mitra tutur dalam suatu komunikasi. Artinya mitra tutur tidak akan merasa sendiri dan akan merasa diperhatikan. Hal ini dapat terlihat pada komentar dalam konteks Jokowi mengunggah pertemuannya dengan tokoh dunia di Bali, salah satunya adalah Sekertaris Jenderal PBB Antonio Gutteres, berikut:

(5) "Jaga kesehatan ya pak, dan kita sebagai rakyat Indonesia, tak henti mendoakan korban gempa dan Indonesia, dan tak lupa kami menyelipkan doa agar bapak diberikan kesehatan dan kekuatan" (didijournal, 19-102018).

Data (5) merupakan wacana politik kesehatan. Komentar tersebut disampaikan oleh pemilik akun Instagram didijournal sebagai respon terhadap unggahan Jokowi. Strategi kesantunan yang digunakan pada wacana tersebut adalah dengan cara melibatkan penutur. Komunikasi politik dalam bidang kesehatan berandil yang besar dalam mewujudkan keberhasilan program atau kebijkan bidang kesehatan pemerintah.

Pelibatan mitra tutur pada wacana politik kesehatan di atas terlihat dengan penggunaan kata kita sehingga memberikan daya kesantunan positif. Oleh karena itu, sebaiknya dalam berkomunikasi menggunakan bahasa yang santun, salah satunya dengan melibatkan penutur dalam komunikasi.

\section{KP-6: Mendramatisasi Fakta}

Mendaramatisasi fakta atau berbohong dengan tujuan kebaikan merupakan salah satu strategi kesantunan berbahasa. Hal ini dilakukan oleh penutur untuk menjaga muka positif mitra tutur. Berikut ini komentar komentar berstrategi kesantunan dengan cara mendramatisasi fakta. Konteksnya adalah Jokowi mengunggah unggahan Eko Yuli Irawan di istana merdeka, setelah pulang dari kejuaraan angkat besi di Turkmenistan.

(6) "Cuma dijaman pak Jokowi Indonesia prestasinya mendunia" (arclim, 8-11-2018).

Data (6) merupakan wacana politik olahraga. Komentar tersebut disampaikan oleh pemilik akun Instagram arclim. Komentar wacana politik olahraga tersebut merupakan bentuk kesantunan berstrategi positif. Hal ini terlihat pada komentar tersebut yang mendaramatisasi fakta.

Prestasi anak bangsa sebelum pemerintahan Jokowi juga pernah mendunia. Misalnya pada pemerintahan sebelumnya, Indonesia pernah mendapat gelar juara umum SEA Games 2011. Komentar yang disampaikan pemilik akun Instagram arclim pada dasarnya digunakan untuk menunjukkan kesantunan terhadap mitra tutur. 
KP-7: Memperhatikan Keinginan Mitra Tutur

Memperhatikan keinginan mitra tutur sebagai salah satu strategi komunikasi untuk memperlihatkan integritas dan solidaritas kepada mitra tutur. Tindak kesantunan berbahasa dapat direalisasikan dengan cara memperhatikan keinginan mitra tutur. Setiap orang pada dasarnya merasa senang apabila keinginannya dapat tercapai. Berikut ini komentar yang memperhatikan keinginan mitra tutur dengan konteks Jokowi bertemu dengan Wakil Presiden Amerika serikat Mike Pance.

(7) "Pantun buat pak Jokowi "anak dara pergi mengaji, sebelum mengaji mandi di kali, jangan lupa pemilu nanti pilih Jokowi sekali lagi" (asausaukani, 1511-2018).

Data (7) merupakan wacana politik kepemimpinan. Komentar tersebut disampaikan oleh pemilik akun Instagram asausaukani. Komentar tersebut merupakan komentar yang santun, hal ini terlihat pada komentar pilih Jokowi sekali lagi.

Fungsi komunikasi kepemimpinan adalah membentuk persepsi bersama. Komentar pada wacana politik kepemimpinan di atas terlihat memperhatikan keinginan mitra tutur. Keinginan yang dimaksud adalah dipilihnya Jokowi sebagai presiden pada periode 2019-2024. Persepsi bersama yang ingin dibangun pada komentar tersebut adalah menjadikan Jokowi sebagai presiden pada periode kedua.

\section{KP-8: Memberikan Janji}

Tindak kesantunan positif berjanji mengikat penutur untuk melakukan sesuatu di masa yang akan datang Tindak komunikasi yang memiliki kepastian akan lebih memberikan rasa senang kepada mitra tutur. Pada dasarnya setiap orang akan lebih senang dengan hal-hal yang pasti. Erikut ini komentar dengan kontes Jokowi mengunggah unggahan mengenai peringatan maulid Nabi Muhammad SAW di Istana Bogor.

(8) "Kami pilih No 1 saja Jokowi_Ma'ruf Amin untuk indenesia maju"

(wawan_jiswan1, 20-11-2018).

Data (8) merupakan wacana politik kepemimpinan. Komentar tersebut disampaikan oleh pemilik akun Instagram wawan_jiswan1 dengan tujuan merespon unggahan Jokowi. Memberikan janji kepada mitra tutur bertujuan menjaga harmoni dan meningkatkan solidaritas. Komentar pada wacana politik kepemimpinan di atas memiliki nilai kesantunan berstrategi positif dengan cara memberikan janji untuk memilih Jokowi menjadi presiden dua periode. Komentar wacana politik kepemimpinan tersebut relevan dengan akan diadakannya pemilihan presiden dan wakil presiden. Selain itu, wacana politik kepemimpinan tersebut relevan dengan studi ini yakni politikopragmatik.

\section{KP-9: Menggunakan Lelucon}

Secara umum fungsi humor dalam komunikasi adalah menyelamatkan wajah positif. Penggunaan lelucon atau humor dalam berkomunikasi memang perlu, karena melalui lelucon tidak jarang membuat mitra tutur merasa senang. Salah satu wujud kesantunan positifdapat direalisasikan dengan menggunakan lelucon pada saat berkomunikasi. Berikut ini komentar dalam kontekas Jokowi mengunggah kebersamaannya dengan Pak Sutopo yang datang di Istana Bogor, yang 
memiliki nilai kesantunan positif dengan cara menggunakan lelucon.

(9) "Potong bebek Angsa:

Potong bebek angsa

Masak di kuali

Bikin maju bangsa

Harus dua kali

Dukung Jokowi

For 2 kali

Tralalalalalala

Jokowi capres

Amin cawapres

Tralalalalalalala

(13_calviendra_reiky, 12-102018)"

Komunikasi kepemimpinan bertujuan untuk mencapai tujuan yang lebih tinggi, khususnya dalam kepemimpinan, dalam konteks data di atas adalah menjadi presiden. Data (9) merupakan wacana politik kepemimpinan. Wacana politik kepemimpinan pada data ini disampaikan oleh pemilik akun Instagram 13_calviendra_reiky.

Penggunaan humor dalam berkomunikasi bertujuan untuk menimbulkan keakraban. Wacana politik kepemimpinan pada data di atas disampaikan dengan lelucon, namun tetap memiliki nilai kesantunan berbahasa. Kesantunan berbahasa pada wacana politik kepemimpinan di atas terlihat pada komentar Dukung Jokowi For 2 kali.

\section{Strategi Kesantunan Negatif (KN)}

Strategi kesantunan negatif
berfungsi untuk mengurangi
ketidaksopanan ilokusioner yang tidak
sopan. Kesantunan negatif berhubungan
dengan bentuk muka negatif. Strategi
kesantunan negatif pada komentar akun
Instagram direalisasikan melalui
beberapa wujud. Berikut ini perwujudan

realisasi kesantunan negatif komentar pada akun Instagram Jokowi yang hadi rdalam bentuk meminta maaf, menunjukkan sikap pesimis, dan menggunakan bentuk impersonal.

\section{KN-1: Meminta Maaf}

Tindak komunikasi akan dapat berjalan dengan baik sesuai dengan tujuan apabila antara penutur dan mitra tutur saling menghormati. Penggunaan kata maaf merupakan salah satu bentuk perhormatan terhadap mitra tutur. Berikut ini komentar yang memiliki nilai kesantunan dengan meminta maaf dalam konteks Jokowi mengunggah unggahan mengenai ajakan untuk percaya diri terhadap bangsa Indonesia.

\section{(10) "Maaf pak Jokowi, saya mau bertanya apakah boleh" (rohmaddarmawan96, 24-1- 2019).}

Data (10) disampaikan oleh pemilik akun Instagram rohmaddarmawan96. Sebagai respon terhadap unggahan Jokowi yang mengajak untuk optimis dalam membangun bangsa Indonesia, komentar ini memiliki kesantunan yang sangat baik, karena kata maaf sebagai wujud hormat dan memohon kepada mitra tutur.

Tindak kesantunan berbahasa pada wacana politik pembangunan memiliki peran yang sangat penting. Penyampaian informasi terkait dengan kesadaran pembangunan sebagai upaya mendukung keberhasilan pembangunan. Oleh karena itu, kesantunan berbahasa dalam menyampaikan informasi pembangunan sangat berperan penting.

\section{KN-2: Menunjukkan Sikap Pesimistis}

Tindak kesantunan komunikasi yang selanjutnya dapat dipilih adalah menunjukkan sikap pesimis. Sikap 
pesimis dalam konteks komentar ini bertujuan untuk menghormati mitra tutur. Berikut ini komentar dalam konteks Jokowi mengunggah unggahan mengenai ajakan untuk percaya diri terhadap bangsa Indonesia, yang memiliki nilai kesantunan dengan sikap pesimis.

(11) "Saya pikir sangat sulit untuk memilih paslon 02 bapak Prabowo dikarenakan harus memakai kata "SANDI" mending pilih Jokowi tinggal bilang "AMIN" yang setuju like" (irfannojm, 24-1-2019).

Data (11) merupakan wacana politik kepemimpinan. Komentar di atas disampaikan oleh pemilik akun Instagram irfannojm. Komentar wacana politik kepemimpinan di atas menunjukkan sikap pesimis penutur apabila memilih paslon 02. Tindak komunikasi kepemimpinan yang harus dibangun oleh pemimpin seharusnya komunikasi yang berdaya kharismatik.

Wacana politik kepemimpinan di atas menunjukkan kesantunan dengan sikap pesimis. Sikap pesimis ini ditunjukkan kepada lawan paslon 02 . Berdasarkan hal tersebut penutur menunjukkan kesantunan karena berusaha menjaga muka mitra tutur dalam konteks ini adalah Jokowi.

\section{KN-3: Menggunakan Bentuk Impersonal}

Strategi kesantunan negatif tindak kesantunan berbahasa selanjutnya adalah menggunakan bentuk impersonal. Bentuk impersonal adalah tidak menyebutkan penutur dan mitra tutur dalam berkomunikasi. Berikut ini komentar yang menggunakan bentuk impersonal dengan konteks Jokowi mengunggah unggahan mengenai kehadiran
Jokowi pada pernikahan Yudani dan Hanifan.

(12) "Benar-benar kebanggaan bangsa. Mau datang ke acara nikahan atlet"

(ayaryaooh, 6-1-2019). Konteks:

Data (12) disampaikan oleh pemilik akun Instagram ayaryaooh dalam rangka mengomentari unggahan Jokowi. Strategi kesantunan yang digunakan penutur dalam berkomentar adalah strategi kesantunan negatif dengan menggunakan bentuk impersonal. Komentar komentar pada data di atas tidak menyebut penutur dan mitra tutur secara langsung.

\section{PENUTUP}

Berdasarkan hasil dan pembahasan yang telah disajikan di atas, dapat disimpulkan strategi kesantunan berkomentar pada akun Instagram Jokowi dibedakan menjadi dua strategi, yakni strategi kesantunan positif dan negatif. Strategi kesantunan positif direalisasikan menjadi sembilan wujud yang meliputi: (1) memberikan perhatian; (2) menunjukkan keoptimisan; (3) menggunakan penanda indentitas; (4) memberikan pertanyaan; (5) melibatkan penutur dalam komunikasi; (6) mengintensifkan perhatian penutur dengan cara mendramatisasi peristiwa dan fakta; (7) memperhatikan keinginan mitra tutur; (8) memberikan janji; (9) menggunakan lelucon.

Strategi kesantunan negatif direalisasikan menjadi tiga wujud yang meliputi: (1) meminta maaf; (2) menunjukkan sikap pesimis; dan (3) menggunakan bentuk impersonal. Strategi kesantunan berbahasa dalam berkomentar pada akun instgram Jokowi memiliki kecenderungan menggunakan 
strategi kesantunan positif. Hal ini menunjukkan netizen akun Instagram Jokowi memiliki kepercayaam terhadap kepemimpinan Jokowi.

\section{DAFTAR PUSTAKA}

Akadun. (2011). Revitalisasi forum musrenbang sebagai wahana partisipasi masyarakat dalam perencanaan pembangunan daerah. Mimbar, Jurnal Sosial dan Pembangunan, 27(2), 183192

(DOI:

10.29313/mimbar.v27i2.327)

Arsith, M., Aurelia, D., \& Popa, T. (2017). Some aspects specific to communication and religious image in christianity. Communication, 11(2), 135-146.

Arumsari, N., Septiana, W. E., Luthfi, M., \& Rizki, N. K. A. (2017). Komunikasi politik kepala desa dalam mendorong inovasi pembangunan desa: Studi kasus tiga desa di lereng gunung Ungaran, Jawa Tengah. Politik Indonesia: Indonesia Political Science Review, 2(1), 86-99.

Aziz, A. A. (2017). Agreement strategies among Malaysian Chinese speakers of English. 3L: The Southeast Asian Journal of English Language Studies, 23(1), 168-189 (DOI: 10.17576/3L2017-2301-12 Agreement)

Dynel, M. (2016). Conceptualizing conversational humour as (im)politeness: The case of film talk. Journal of Politeness Research 2016, 12(1), 117-147 (DOI: 10.1515/pr-2015-0023)

Fauziati, E. (2016). Applied Linguistics Principle of Foreign Language Teaching, Learning, and Researching. Surakarta: Era Pustaka Utama.
Gunawan, F. (2014). Representasi kesantunan Brown dan Levinson dalam wacana akademik. Kandai, 10(1), 16-27 (DOI: 10.26499/jk.v10i1.309)

H.K, T., M, L, T., \& S.K, T. (2014). Beyond 'greeting' and 'thanking': Politeness in job interviews. 3L: The Southeast Asian Journal of English Language Studies, 22(3), 171184.

Halid, E. (2017). Kesantunan berbahasa dalam kegiatan diskusi mahasiswa angkatan 2016 Program Studi DIII Keperawatan Solok Poltekes Kemenkes Padang. Bahastra, 37(1), 1-8 (DOI:10.26555/bahastra.v37i1.59 57).

Hamzah, Z. A. Z., \& Hassan, A. F. M. (2012). Penggunaan strategi ketidaksantunan dalam kalangan remaja di sekolah. Jurnal Linguistik, 16(Desember), 62-74.

Hendrastuti, R. (2017). Refleksi sikap dalam kesantunan komentar cerpen anak. Sawerigading, 23(2), 229-239 (DOI: 10.26499/sawer.v23i2.257).

Jabbarifar, T. (2016). The importance of human communication systems and the teaching of the english language. Journal of International Education Research (JIER), 10(3), 219 (DOI: 10.19030/jier.v10i3.8741).

Jamal, J., \& Bakar, H. A. (2017). The mediating role of charismatic leadership communication in a crisis: A Malaysian example. International Journal of Business Communication, 54(4), 369-393 (Doi: 10.1177/23294884155727 82). 
Jauhari, E. (2018). Alat-alat kesantunan kritik dalam masyarakat Jawa surabaya: Kajian pragmatik. Mozaik Humaniora, 18(2), 167177 (DOI: $10.20473 / \mathrm{mh} . v 18 \mathrm{i} 2.10$ 931).

Jauhari, E., \& Sugiri, E. (2012). Kesantunan positif dalam masyarakat etnik Tionghoa di Surakarta: Kajian Sosiopragmatik. Mozaik: Jurnal Ilmu Humaniora, 12(2), 105-121.

Jauhari, E., \& Susanto, D. (2014).

Realisasi kesantunan positif dalam masyarakat etnik Tionghoa di Surakarta. Prosiding. Seminar Nsional Prasasti (Pragmatik dan Linguistik), hlm. 61-72

(DOI:

10.20961/pras.v0i0.524).

Kamlasi, I. (2017). The positive politeness in corversations performed by the students of English study program of Tomor University. Metathesis, 1(2), 6881

(DOI:

10.31002/metathesis.v1i2.466).

Kousar, S. (2015). Politeness orientation in social hierarchies in Urdu. International Journal of Society, Culture \& Language, 3(2), 8596.

Kusno, A., \& Rahman, A. (2016). Bentuk-bentuk pelanggaran prinsip kesopanan dalam ceramah keagamaan. Lingua: Jurnal Ilmu Bahasa dan Sastra, 11(2), 103-115 (DOI: 10.18860/ling.v11i2.3502).

Leech, G. (2014). The Pragmatics of Politness. New York: Oxford University Press.

Listyawati, D., Sarmiati, \& Asmawi. (2019). Komunikasi perangkat nagari dan partisipasi masyarakat dalam pengelolaan dana desa. JISPO, 9(1), 97-106 (DOI: 10.15575/jispo.v9i1.4143).
Mahsun, M. (2014). Metode penelitian bahasa: tahapan, strategi, dan tekniknya. Jakarta: Raja Grafindo Persada.

Mansor, N. S., Mamat, R., Omar, R. C., \& Ghazali, A. H. A. (2014). Ketidaksantunan bahasa sebagai strategi pujukan dalam iklan berbahasa Sepanyol. Gema Online Journal of Language Studies, 14(3), 207-223 (DOI: 10.17576/GEMA-2014-1403-13

Markhamah \& Sabardila, A. (2009). Analisis kesalahan dan kesantunan berbahasa. Surakarta: Muhammadiyah University Press.

Maros, M., \& Rosli, L. (2017). Politeness strategies in twitter updates of female english language studies Malaysian undergraduates. $3 \mathrm{~L}$ : $\quad$ The Southeast Asian Journal of English Language Studies, 23(1), 132-149 (DOI: 10.17576/3L2017-2301-10 Politeness).

Mayfield, J., \& Mayfield, M. (2016). Leadership communication: reflecting, engaging, and innovating. International Journal of Business Communication, 54(1), 3-11 (DOI: 10.1177/2329488416675446).

Mayfield, M., \& Mayfield, J. (2017). "Whats past is prologue": A look at past leadership communication research with a view toward the future. International Journal of Business Communication, 54(2), 107-114 (DOI: $10.1177 / 2329488416687050)$.

Muhawarman, A., Ayuningtyas, D., \& Misnaniarti. (2017). Formulasi kebijakan komunikasi untuk pelaksanaan program pembangunan kesehatan. Jurnal MKMI, 13(2), 97-106. 
Ngalim, A., Markhamah, \& Prayitno, H. J. (2015). Sosiolinguistik: Suatu kajian fungsional (Edisi Revi). Sukoharjo: Jasmine.

Nickerson, C., \& Goby, V. P. (2017). New lamps for old: The gulf leadership communication framework. International Journal of Business Communication, 54(2), $\quad$ 182-198 (DOI: 10.1177/2329488416687055).

Noor, K. U., \& Prayitno, H. J. (2016). Pergeseran kesantunan positif siswa kelas IX MTsN 1 Surakarta berlatar belakang budaya Jawa. Kajian Linguistik dan Sastra, 1(1), 17-24 (DOI: 10.23917/kls.v1i1.247).

Pramujiono, A. (2008). Kesantunan positif komunikasi dokter-pasien dalam program konsultasi seks. Linguistik Indonesia, 26(2), 151167.

Prayitno, H. J. (2015). Tindak kesantunan berbahasa dalam dialektika pembelajaran pragmatik: Berdaya, berorientasi, dan berstrategi kesantunan positif. Prosiding. Seminar Nasional Prasasti "Kajian Pragmatik Dalam Berbagai Bidang, 24-35.

Prayitno, H. J., Ngalim, A., Sutopo, A., Rohmadi, M., \& Yuniawan, T. (2018). Power, orientation, and strategy of positive politeness used by children at the age elementary school with Javanese cultural backgraund. Humanus, 17(2), 164-173 (DOI: 10.24036/humanus.v17i2.101371

Rija, M. (2016). Positive politness strategies in the novel "the client": A sociopragmatik study. Metalingua, 14(2), 209-224 (DOI:

10.26499/metalingua.v14i2.197).
Saleh, M., \& Baharman. (2012). Kesantunan tindak tutur dalam interkasi akademik. Jurnal Retorika, 8(2), 123-133 (DOI: 10.26858/retorika.v8i2.3625).

Saputry, D. (2016). Strategi kesantunan positif dan negatif dalam bentuk komentar direktif di lingkungan STKIP Muhammadiyah Pringsewu, Lampung. Jurnal Pesona, 2(1), 149-160.

Sudaryanto. (2015). Metode dan aneka teknik analisis bahasa: Pengantar penelitian wahana kebudayaan secara Linguistik. Yogyakarta: Sanata Dharma University Press.

Sukarno. (2018). Politeness strategies, linguistic markers and social contexts in delivering requests in javanese. Indonesian Journal of Applied Linguistics, 7(3), 659667

(DOI:

10.17509/ijal.v7i3.9816).

Syaifudin, Z. K. (2017). Implikatur dan kesantunan positif komentar Jokowi dalam talkshow Mata Najwa dan implementasinya sebagai bahan ajar bahasa Indonesia di SMK. Jurnal Penelitian Humaniora, 14(1), 5570

(DOI: 10.23917/humaniora.v14i1.886).

Ulum, D. E. L., \& Kusmanto, H. (2018). Disfemia pada komentar akun instagram Mimi.Peri. Prosiding. Seminar Kajian Bahasa, Sastra, dan Pengajarannya V, 232-237.

Zamzani. (2010). Pengembangan alat ukur kesantunan bahasa Indonesia dalam interaksi sosial bersemuka dan nonbersemuka. Litera, 5(1), 265-288 (DOI: 10.21831/ltr.v10i1.1171). 